\title{
Analisis Hubungan Umur Dan Paritas dengan Kejadian Anemia Pada Ibu Hamil
}

\author{
Aminah Maya \\ Program Studi DII Kebidanan IKesT Muhammadiyah Palembang \\ Korespondensi email: mayachabie@gmail.com
}

\begin{abstract}
ABSTRAK
Pendahuluan: Anemia pada ibu hamil masih menjadi prioritas penanganan masalah kesehatan oleh Kementerian Kesehatan. Banyak faktor yang mempengaruhi kejadian anemia pada ibu hamil. Jarak antara kehamilan sebelumnya dan berikutnya yang pendek atau singkat, misalnya kurang dari 2 tahun, dapat meningkatkan risiko kejadian anemia pada ibu hamil. Begitu juga dengan umur ibu saat hamil, umur di bawah 20 tahun dan di atas 35 tahun memiliki risiko yang signifikan dengan kejadian anemia. Metode: Jenis penelitian observasional dengan desain cross sectional yang dilakukan di Rumah Sakit Muhammadiyah Palembang Tahun 2017. Sampel penelitian adalah 34 orang ibu hamil yang didapatkan dengan menggunakan teknik accidental sampling. Analisis univariat digunakan untuk mengetahui distribusi karakteristik responden dan analisis bivariat dengan menggunakan uji chi square. Hasil: Dari hasil uji statistik menunjukkan bahwa tidak ada hubungan antara umur ibu dengan kejadian anemia $(\rho: 0.289>0,05)$. Dan untuk hasil analisis hubungan antara paritas ibu dan kejadian anemia, menunjukkan bahwa ada hubungan yang signifikan antara paritas ibu dengan kejadian anemia pada ibu hamil $(\rho: 0,041<0,05)$. Diskusi: umur bukan satu-satunya faktor penyebab anemia melainkan ada faktor lain yaitu faktor dasar (sosial ekonomi, pengetahuan, pendidikan, dan budaya) dan faktor langsung (pola konsumsi tablet tambah darah, infeksi dan perdarahan. Wanita yang sering mengalami kehamilan dan melahirkan makin anemia karena banyak kehilangan zat besi, hal ini disebabkan selama kehamilan wanita menggunakan cadangan besi yang ada di dalam tubuhnya.
\end{abstract}

Kata Kunci: Kejadian anemia, umur, paritas

\section{The Relationship Analysis Of Age and Parity with Incidence Of Anemia in Pregnant Women}

\begin{abstract}
Introduction: Anemia in pregnant women is still a priority for handling health problems by the Ministry of Health. Many factors influence the incidence of anemia in pregnant women. The distance between the previous and subsequent pregnancies is short or short, for example less than 2 years, can increase the risk of anemia in pregnant women. Likewise, the age of the mother at pregnancy, age under 20 years and over 35 years have a significant risk of anemia. Methods: This type of observational study with a cross sectional design was conducted at the Muhammadiyah Palembang Hospital in 2017. The sample of the study was 34 pregnant women who were obtained using accidental sampling technique. Univariate analysis was used to determine the distribution of respondent characteristics and bivariate analysis using the chi square test. Results: From the results of statistical tests showed that there was no relationship between maternal age and the incidence of anemia ( $\rho: 0.289)$. And the results of the analysis of the relationship between maternal parity and the incidence of anemia showed that there was a significant relationship between maternal parity and the incidence of anemia in pregnant women.. Discussion: age is not one the only factors that cause anemia, but there are other factors, namely basic factors (socioeconomic, knowledge, education, and culture) and direct factors (consumption patterns of supplemented blood tablets, infection and bleeding. Women who often experience pregnancy and childbirth are increasingly anemic because of a lot of substance loss iron, this is because during pregnancy a woman uses iron reserves in her body.
\end{abstract}

Keywords: Incidence of anemia, age, parity 


\section{PENDAHULUAN}

Saat ini status kesehatan ibu dan anak di Indonesia masih jauh dari yang diharapkan, ditandai dengan masih tingginya AKI dan AKB. Berdasarkan Survei Demografi dan Kesehatan Indonesia (SDKI) 2012 didapatkan data AKI sebesar 359 per 100.000 kelahiran hidup, mengalami peningkatan jika dibandingkan dengan AKI tahun 2007 yaitu 228 per 100.000 kelahiran hidup. Menurut catatan dan perhitungan Departemen Kesehatan pendarahan menempati presentase tertinggi penyebab kematian ibu, anemia dan kurangnya energi kronis (KEK) pada ibu hamil menjadi penyebab utama terjadinya perdarahan dan infeksi merupakan faktor kematian utama ibu.

Anemia merupakan masalah kesehatan masyarakat terbesar di dunia terutama bagi kelompok wanita usia reproduksi (WUS). Anemia pada wanita usia subur (WUS) dapat menimbulkan kelelahan, badan lemah, penurunan kapasitas atau kemampuan atau produktifitas kerja. Anemia pada ibu hamil masih menjadi prioritas penanganan masalah kesehatan oleh kementerian kesehatan. Hal ini terlihat dari masih dilakukannya intervensi pemberian tablet zat besi pada ibu hamil selama kehamilan di seluruh Puskesmas di Indonesia. Menurut Arisman (2008), Penyebab paling umum dari anemia pada kehamilan adalah kekurangan zat besi, asam folat, dan perdarahan akut dapat terjadi karena interaksi antara keduanya (Noverstiti, 2012). Anemia adalah keadaan dimana massa eritrosit dan atau massa hemoglobin yang beredar tidak dapat memenuhi fungsinya untuk menyediakan oksigen bagi jaringan tubuh (Bakta, 2011).

Anemia merupakan kelainan hematologis yang paling umum terjadi pada kehamilan. Menurut standar terbaru yang ditetapkan oleh WHO, digolongkan anemia jika konsentrasi Hemoglobin $(\mathrm{Hb})$ pada darah perifer adalah $11 \mathrm{gr} / \mathrm{dl}$ atau kurang. Anemia dalam kehamilan adalah kondisi ibu dengan jumlah protein sel darah merah dan zat pewarna merah pada sel darah dibawah $11 \%$ gram pada usia kehamilan 4-7 bulan. Anemia pada ibu hamil bisa menyebabkan banyak masalah. Pada anemia yang berat bisa meningkatkan risiko kematian ibu dalam proses persalinan (Amirullah dalam Jasmi,2016). Hasil penelitian Fakultas Kedokteran di seluruh Indonesia menunjukkan prevalensi anemia pada ibu hamil di Indonesia adalah 50$63 \%$,sedangkan penelitian Pusponegoro dan Anemia World Map pada waktu yang sama menyebutkan $51 \%$ wanita hamil menderita anemia sehingga menyebabkan kematian hingga 300 jiwa perhari (Sabinah, 2015).

$$
\text { Banyak faktor yang }
$$

mempengaruhi kejadian anemia pada ibu hamil. Jarak antara kehamilan sebelumnya dan berikutnya yang pendek atau singkat, misalnya kurang dari 2 tahun, dapat meningkatkan risiko kejadian anemia pada ibu hamil. Begitu juga dengan umur ibu saat hamil, umur di bawah 20 tahun dan di atas 35 tahun memiliki risiko yang signifikan dengan kejadian anemia. Berdasarkan penelitian yang dilakukan oleh Fikriana, dkk (2013) menyimpulkan bahwa terdapat hubungan antara jumlah paritas, umur dan status gizi terhadap anemia pada ibu hamil di Puskesmas Kasihan II Bantul.

Anemia merupakan salah satu resiko terjadinya bayi dengan berat badan lahir rendah (BBLR), infeksi terhadap janin dan ibu, keguguran, kelahiran prematur dan kematian ibu. Penelitian dengan total sampel 245.407 dalam sebuah meta-analisis yang berjudul "maternal anemia during pregnancy and infant low birth weight" menunjukkan bahwa risiko relatif pada anemia pada trimester pertama, kedua dan ketiga kehamilan adalah 1.26 (95\% Cl: 1.03-1.55), 0.97 (95\% Cl: 0.57-1.65), dan $1.21 \quad(95 \% \quad \mathrm{Cl}$ : 0.84-1.76). Kesimpulan dari meta-analisis ini adalah anemia maternal, terutama pada trimester pertama kehamilan dianggap 
sebagai faktor risiko untuk hasil kehamilan (Rahmawati, 2017).

Penelitian berjudul Anemia and Associated Factors Among Pregnant Women Atteding Antenatal Care Clinic in Wolayita Sodo Town, Southern Ethiopia dengan desain penelitian cross sectional dan sampel 363 ibu hamil menghasilkan beberapa prediktor independen anemia pada ibu hamil yaitu usia 15-24 tahun, jumlah keluarga $>5$, multigravida, memiliki pendapatan rendah, penyakit klinis yang diderita saat ini, infeksi parasit usus, tidak ada riwayat penggunaan kontrasepsi, kehamilan trimester ketiga, perdarahan mentruasi berlebihan dan indeks massa tubuh rendah. Namun masih terdapat perbedaan dari beberapa penelitian mengenai hubungan paritasdan umur ibu hamil dengan kejadian anemia (lealem, 2015).

\section{BAHAN DAN METODE}

Jenis penelitian ini adalah observasional dengan desain cross sectional yang dilakukan di Rumah Sakit Muhammadiyah Palembang Tahun 2017 serta Laboratorium Medik Prodia
Palembang untuk pemeriksaan kuantitatif kadar hemoglobin pada ibu hamil. Populasi dalam penelitian ini adalah seluruh ibu hamil memeriksakan kehamilananya di Poli Kebidanan Rumah Sakit Muhammadiyah Palembang. Sampel penelitian adalah ibu hamil sebanyak 34 orang yang didapatkan dengan menggunakan teknik pengambilan sampel accidental sampling. Variabel independen berupa umur ibu dan paritas dan variabel dependennya adalah anemia. Data umur ibu dan paritas diperoleh dengan menggunakan kuesioner. Data anemia ibu hamil diperoleh dari hasil pemeriksaan laboratorium. Analisis univariat digunakan untuk mengetahui distribusi karakteristik responden dan analisis hubungan antar variabel diketahui dengan menggunakan uji chi square.

\section{HASIL}

Dari hasil penelitian yang dilakukan pada 34 responden, didapatkan hasil sebagai berikut:

Tabel 1.

Hubungan Umur ibu dan Kejadian Anemia

\begin{tabular}{lccccc}
\hline \multirow{2}{*}{ Umur } & \multicolumn{3}{c}{ Anemia } & & \multirow{2}{*}{ P value } \\
\cline { 2 - 3 } & tidak anemia & Anemia & Total & \\
\hline Risiko rendah & 11 & 20 & 31 & \\
\hline Risiko Tinggi & 2 & 1 & & \\
\hline Total & 13 & 21 & 34 & \\
\hline
\end{tabular}

Tabel 2.

Hubungan Paritas ibu dan Kejadian Anemia

\begin{tabular}{|c|c|c|c|c|}
\hline \multirow[b]{2}{*}{ Paritas } & \multicolumn{2}{|c|}{ anemia } & \multirow[b]{2}{*}{ Total } & \multirow{2}{*}{$P$ value } \\
\hline & tidak anemia & Anemia & & \\
\hline Primipara & 6 & 3 & 9 & \multirow{3}{*}{0,041} \\
\hline Multipara & 7 & 18 & 25 & \\
\hline Total & 13 & 21 & 34 & \\
\hline
\end{tabular}

Tabel 1. Dari hasil uji statistik menggunakan chi square untuk mengetahui hubungan antara umur ibu dan kejadian anemia, diperoleh tingkat signifikansi $\rho>0.05$ ( $\rho: 0.289$ ) sehingga dapat disimpulkan bahwa tidak ada 
hubungan antara umur ibu dengan kejadian anemia.

Tabel 2. Dari hasil uji statistik menggunakan chi square untuk mengetahui hubungan antara paritas ibu dan kejadian anemia, diperoleh tingkat signifikansi $\rho<0.05$ ( $\rho: 0.041$ ) sehingga dapat disimpulkan bahwa ada hubungan antara paritas ibu dengan kejadian anemia pada ibu hamil.

\section{PEMBAHASAN}

Defisiensi zat besi timbul pada saat kebutuhan akan zat besi meningkat, misalnya pada wanita usia reproduktif. Pada tingkat umur yang berbeda, terdapat varian kebutuhan zat besi setiap hari. Konsentrasi HB yang rendah berhubungan dengan usia ibu yang akstrime (terlalu tua atau terlalu muda). Pada usia kurang dari 20 tahun kondisi masih dalam pertumbuhan, sehingga masukan makanan banyak dipakai untuk pertumbuhan ibu yang dapat mengakibatkan gangguan pertumbuhan janin. Hal tersebut dikuatkan dengan sebuah penelitian yang telah dilakukan di Southern Ethiopia pada tahun 2015 menunjukan bahwa ibu hamil dengan umur 15-24 tahun (AOR: 9.89, 95\% $\mathrm{Cl}: 2.68-21.41)$ merupakan salah satu prediktor independen anemia pada ibu hamil (Demmouche, 2011), Sedangkan pada ibu hamil di atas usia 35 tahun cenderung mengalami anemia disebabkan karena pengaruh turunnya cadangan zat besi dalam tubuh.

Pada kehamilan pertama pada wanita berusia di atas 35 tahun juga akan mempunyai risiko penyulit persalinan dan mulai terjadinya penurunan fungsifungsi organ reproduksl (Demmouche,2011). Hasil penelitian ini juga sesuai dengan penelitian yang dilakukan oleh Majidah, 2018 yang mendapatkan nilai $p$ value sebesar 0.243 yang berarti tidak ada hubungan bermakna antara umur ibu dengan anemia pada ibu hamil trimester III di Kota Yogyakarta tahun 2017.

Hasil penelitian ini juga sejalan dengan hasil penelitian yang dilakukan di Puskesmas Bangtayu kecamatan Genuk, Kota Semarang tahun 2012 yang menunjukkan uji Korelasi Pearson Product Momen dan didapatkan hasil bahwa hubungan antara umur ibu dengan anemia pada ibu hamil trimester III mempunyai Korelasi Pearson sebesar 0.215 , sehingga dapat disimpulkan bahwa terdapat hubungan yang lemah dengan arah hubungan yang positif yaitu semakin tinggi umur, maka semakin tinggi anemia. Sedangkan p-value sebesar 0.095 yang menunjukan bahwa tidak ada hubungan signifikan antara umur dengan anemia ibu hamil trimester III (Qudsiah,2012). Hal ini disebabkan bahwa umur bukan satu-satunya faktor penyebab anemia melainkan ada faktor lain yaitu faktor dasar (sosial ekonomi, pengetahuan, pendidikan, dan budaya) dan faktor langsung (pola konsumsi tablet tambah darah, infeksi dan perdarahan).

Beberapa faktor yang dapat menyebabkan terjadinya anemia kehamilan diantaranya gravid, umur, paritas, tingkat pendidikan, status ekonomi dan kepatuhan konsumsi tablet Fe (Keisnawati, dkk, 2015). Faktor yang kemungkinan paling mempengaruhi yaitu paritas karena meskipun ibu hamil berusia reproduktif (tidak berisiko) namun mayoritas ibu hamil merupakan nulipara dan primipara (berisiko). Penelitian ini juga mendapatkan hasil nilai $p$-value sebesar 0.041 untuk variabel paritas yang berarti ada hubungan yang bermakna antara paritas dengan anemia pada ibu hamil. Hal ini sesuai dengan penelitian yang dilakukan pada ibu hamil trimester III di Kota Yogyakarta tahun 2017. Berdasarkan nilai Rasio Prevalens (RP) didapatkan nilai sebesar 0.328 yang berarti paritas merupakan faktor protektif, bukan faktor risiko.

Ibu hamil dengan paritas $<1$ lebih aktif untuk mendapatkan informasi tentang kehamilan sehingga dapat mencegah terjadinya anemia. Di negara yang sedang berkembang terutama di daerah pedesaan, ibu-ibu yang berasal dari tingkat sosial ekonomi yang rendah dengan jumlah anak yang banyak dan jarak kehamilan dekat serta masih menyusui untuk waktu yang panjang 
tanpa memperhatikan gizi saat laktasi akan sangat berbahaya bagi kelangsungan hidupnya dan sering sekali menimbulkan anemia.

Paritas merupakan jumlah anak lahir hidup dan mati. Setiap persalinan akan terjadi pendarahan kurang lebih 400cc. Keadaan tersebut menyebabkan penurunan cadangan zat besi. Jika zat gizi dan zat besi ibu tidak tersuplai sesuai kebutuhan tubuh ibu maka dapat berdampak terhadap anemia. Menurut Wahyuddin disitasi oleh Ariyani (2016) bahwa terdapat kecenderungan, jika semakin banyak jumlah kelahiran (paritas), maka akan semakin tinggi angka kejadian anemia. Paritas $>3$ mempunyai angka kematian maternal lebih tinggi. Lebih tinggi paritas, lebih tinggi kematian maternal. Risiko pada paritas rendah dapat ditangani dengan asuhan obstetrik lebih baik, sedangkan risiko pada paritas tinggi dapat dikurangi atau dicegah dengan keluarga berencana. Sebagian kehamilan pada paritas adalah tidak direncanakan (Herlina, 2009). Paritas merupakan salah satu faktor penting dalam kejadian anemia zat besi pada ibu hamil. Menurut Manuaba (2010). Hasil penelitian ini juga sesuai dengan hasil penelitian dari Salmariantyty, 2012 yang menyatakan bahwa wanita yang sering mengalami kehamilan dan melahirkan makin anemia karena banyak kehilangan zat besi, hal ini disebabkan selama kehamilan wanita menggunakan cadangan besi yang ada di dalam tubuhnya (Salmariantyty, 2012)

\section{SIMPULAN DAN SARAN Simpulan}

Tidak ada hubungan antara umur ibu hamil dengan kejadian anemia dan ada hubungan antara paritas dengan kejadian anemia pada ibu hamil

\section{Saran}

Diharapkan agar pada penelitian selanjutnya dapat menggunakan sampel dengan jumlah yang lebih besar dan dapat menggunakan kriteria inklusi dan eksklusi agar sampel dapat lebih homogeny

\section{KEPUSTAKAAN}

Arisman (2008). Gizi dalam Daur Kehidupan. Bagian IImu Gizi Proyek Peningkatan Penelitian. DIKTI Depdiknas. Palembang: Fakultas Kedokteran USRI.

Bakta (2011). Hematologi Klinik Ringkas. Jakarta:EGC

Sabina, Shaikh dkk. "An Overview of Anemia in Pregnancy". Journal of innovations in Pharmaceuticals and Biological Sciences (JIPBS). Vol 2. No. 2. hlm. 144-151. 2015

Fikriana, dkk (2013). Faktor-Faktor yang Mempengaruhi Kejadian Anemia pada lbu Hamil di PuskesmasKasihan Bantul II. Jurnal Unisa. Yogyakarta.

Rahmati, Shoboo dkk. "Maternal Anemia during pregnancy and infant low birth weight: A systematic review and Meta-analysis". International Journal of Reproductive BioMedicine. Vol 15. No. 3. hlm. 125-134. 2017

Lealem G. et al. "Anemia and Associated Factors Among Pregnant Women Atteding Antenatal Care Clinic in Wolayita Sodo Town, Southern Ethiopia". Ethiop J Health Sci. Vol 25. No 2. 2015

Demmouche A, Khelil S, and Moulessehoul S. "Journal An Epidemiologic Study : Anemia Among Pregnant Women in the Sidi Bel Abbes Region (West Algeria)". Journal of Blood Disorders and Transfusion 2:113. 2011

Majidah, Andini. 2018. Hubungan antara paritas dan umur ibu dengan anemia pada ibu hamil trimester III di Kota Yogyakarta Tahun 2017.

Qudsiah, Djarot, dan Nurjanah. "Hubungan antara Paritas dan Umur lbu dengan Anemia pada lbu Hamil Trimester III tahun 2012". Jurnal Unimus.www.jurnal.unimus.ac.id

Herlina (2009). Faktor-faktor yang Berhubungan dengan Kejadian Anemia Pada Ibu Hamil. Makassar: FKM UNHAS

Jasmi. 2016. Hubungan antara paritas dan umur dengan kejadian anemia 
pada ibu hamil di puskesmas melur kecamatan sukajadi kota pekanbaru. Jurnal ibu dan anak. Volume 1 , nomor 2, November 2016 Halaman 43-50

Noverstiti, Elsy. (2012). Faktor- faktor yang Berhubungan dengan Kejadian Anemia pada Ibu Hamil Trimester III di Wilayah Kerja Puskesmas Air Dingin Kota Padang tahun 2012. STIKES Peringsewu Lampung.
Krisnawati., Desi Ari Madi Yanti., Apri Sulistianingsih. (2015). Faktor-faktor terjadinya anemia pada ibu primigravida di wilayah kerja Puskesmas tahun 2015. STIKES Peringsewu Lampung.

Salmariantity. (2012). Faktor- faktor yang Berhubungan dengan Anemia pada Ibu Hamil di Wilayah Kerja Puskesmas Gajah Mada Tembilahan Kabupaten Indragiri Hilir tahun 2012. Jakarta: FK UI 